\title{
A randomized placebo-controlled phase I clinical trial to evaluate the immunomodulatory activities of Atractylodes lancea (Thunb) DC. in healthy Thai subjects
}

\author{
Inthuon Kulma ${ }^{1,2}$, Luxsana Panrit ${ }^{3}$, Tullayakorn Plengsuriyakarn ${ }^{1,2}$, Wanna Chaijaroenkul ${ }^{1,2}$,
} Siriprapa Warathumpitak ${ }^{1,2}$ and Kesara Na-Bangchang ${ }^{1,2,3^{*}}$

\begin{abstract}
Background: Atractylodes lancea (Thunb) DC. (AL) and bioactive compounds $\beta$-eudesmol and atractylodin have been demonstrated in the in vitro and in vivo studies for their potential clinical use in cholangiocarcinoma. The study was a randomized, double-blinded, placebo-controlled phase I clinical trial to evaluate the immunomodulatory effect of AL in human subjects.

Methods: The modulatory effects of AL and $\beta$-eudesmol and atractylodin on TNFa and IL6 expression in PBMCs were measured using real-time PCR. Blood samples were collected from forty-eight healthy subjects following oral administration of a single or multiple dosing of capsule formulation of the standardized AL extract or placebo. Serum cytokine profiles, lymphocyte subpopulations (B lymphocytes, CD8 ${ }^{+}$cytotoxic T lymphocytes, CD4 ${ }^{+}$T-helper lymphocytes, and NK cells), and cytotoxic activity of PBMCs against the cholangiocarcinoma cell line CL-6 were evaluated using cytometric bead array (CBA) with flow cytometry analysis.

(Continued on next page)
\end{abstract}

\footnotetext{
* Correspondence: kesaratmu@yahoo.com

${ }^{1}$ Graduate Program in Bioclinical Sciences, Chulabhorn International College of Medicine, Thammasat University (Rangsit Campus), Pathumthani 12121, Thailand

${ }^{2}$ Center of Excellence in Pharmacology and Molecular Biology of Malaria and Cholangiocarcinoma, Thammasat University (Rangsit Campus), Pathumthani 12121, Thailand

Full list of author information is available at the end of the article
}

\section{$\triangle B M C$}

(c) The Author(s). 2021 Open Access This article is licensed under a Creative Commons Attribution 4.0 International License, which permits use, sharing, adaptation, distribution and reproduction in any medium or format, as long as you give appropriate credit to the original author(s) and the source, provide a link to the Creative Commons licence, and indicate if changes were made. The images or other third party material in this article are included in the article's Creative Commons licence, unless indicated otherwise in a credit line to the material. If material is not included in the article's Creative Commons licence and your intended use is not permitted by statutory regulation or exceeds the permitted use, you will need to obtain permission directly from the copyright holder. To view a copy of this licence, visit http://creativecommons.org/licenses/by/4.0/. The Creative Commons Public Domain Dedication waiver (http://creativecommons.org/publicdomain/zero/1.0/) applies to the data made available in this article, unless otherwise stated in a credit line to the data. 
(Continued from previous page)

Results: AL extract at almost all concentrations significantly inhibited both TNFa and IL6 expression in Con Amediated inflammation in PBMCs. $\beta$-Eudesmol at all concentrations significantly inhibited only IL6 expression. Atractylodin at the lowest concentration significantly inhibited the expression of both cytokines, while the highest concentration significantly inhibited only IL6 expression. The administration of AL at a single oral dose of $1000 \mathrm{mg}$ appeared to decrease IFNY and IL10 and increase B cell, while significantly increase NK and CD4 ${ }^{+}$and CD8 ${ }^{+}$cells. A trend of increasing (compared with placebo) in the cytotoxic activity of PBMCs at $24 \mathrm{~h}$ of dosing was observed. AL at multiple dosing of $1000 \mathrm{mg}$ for 21 days tended to decrease the production of all cytokines, while significantly inhibited IL17A production at $24 \mathrm{~h}$ of dosing. In addition, a significant increase in CD4 ${ }^{+}$and CD $8^{+}$cells was observed. A trend of increase in the cytotoxic activity of PBMCs was observed at $24 \mathrm{~h}$ but terminated at $48 \mathrm{~h}$ of dosing.

Conclusions: The results confirm the immunomodulatory activity of AL in humans. This activity, in complementary with the direct action of AL on inducing cholangiocarcinoma cell apoptosis, suggests its potential role for CCA control.

Trial registration: Retrospectively registered on 17 October 2020 [Thai Clinical Trials Registry (TCTR: Www.clinical trials.in.th) Number TCTR20201020001].

Keywords: Atractylodes lancea, $\beta$-Eudesmol, Atractylodin, Cholangiocarcinoma, Immunomodulatory activity

\section{Background}

Cholangiocarcinoma (CCA) is a fatal disease with the highest incidence in Southeast Asia, particularly Thailand [1]. Clinical efficacy and tolerability of the current chemotherapeutic drugs remain unsatisfactory. Development of alternative medicines, including those from natural sources is urgently needed. Several risk factors, i.e, bile duct disorders, liver diseases, digestive disorders, metabolic and endocrine disorders, and parasitic infections (Opisthorchis viverrine and Clonorchis sinensis) [1] cause chronic biliary inflammation and cholestasis, resulting in uncontrolled proliferation, genetic and epigenetic mutations and eventually malignant transformation and tumor formation [2]. The proinflammatory cytokines, i.e., tumor necrosis factor-alpha (TNF $\alpha$ ), interleukin (IL) 6 and 8 (IL6, IL8), and nitric oxide synthase (NOS) which are released during tissue injury and chronic inflammation of biliary tree, promote cholangiocarcinogenesis through different signalling pathways involved in cell growth, apoptosis, invasiveness, and angiogenesis [3]. TNF $\alpha$ and IL6 are proinflammatory cytokines that modulate the growth, differentiation and proliferation of various types of cells, including CCA [3]. The level of IL6 was found to be increased in serum and bile of patients with CCA and CCA cell lines [4, 5]. CCA tumor microenvironment plays a vital role in the regulation of tumor proliferation, angiogenesis, invasion, and preventing tumor cells from organismal immune reactions and apoptosis [6]. Tumorassociated macrophages (TAMs) are the most relevant infiltrating immune cell population within the tumor microenvironment [7]. TAMs modulate the CCA microenvironment by secreting TNF $\alpha$, TGF $\beta$ (tumor growth factor- $\beta$ ), IL6, IL10, and VEGF-A (vascular endothelial growth factor-A), which support epithelial-tomesenchymal transition (EMT), tumor growth, and metastasis [8].

The dried rhizome of Atractylodes lancea (Thunb) DC. (AL) has been used in Chinese ("Cang Zhu"), Japanese ("So-jutsu"), and Thai ("Khod-Kha-Mao") traditional medicines for various pharmacological properties including anticancer, anti-inflammatory, antimicrobial activities, and activities on central nervous, cardiovascular, and gastrointestinal systems. Interestingly, the crude extract of AL and its bioactive compounds $\beta$-eudesmol and atractylodin have been demonstrated in a series of both in vitro and in vivo studies for their potential clinical use for CCA control [9]. The immunomodulatory activity of AL and its bioactive compounds in complementary with their direct action on inducing effects on CCA cell apoptosis [10-12] would support the potential role of AL for CCA control. The immunomodulatory activity of this plant, as well as some of its isolated compounds, has also been demonstrated [13]. The present study was a randomized, double-blinded, placebocontrolled phase I clinical trial to evaluate the immunomodulatory activity of AL in humans. The changes in the pro-inflammatory (IL2, IL4, IL6, IL17A, TNF $\alpha$, and IFN $\gamma$ ) and anti-inflammatory (IL10) cytokine profiles, lymphocyte subpopulations, i.e., B lymphocytes, $\mathrm{CD}^{+}$ cytotoxic $\mathrm{T}$ lymphocytes, CD4 ${ }^{+} \mathrm{T}$-helper lymphocytes, and NK (natural killer) cells, and cytotoxic activity against CCA cell line, of peripheral blood mononuclear cells (PBMCs) from healthy subjects following the administration of a single and multiple dose regimens of the capsule formulation of the standardized AL extract were investigated. The confirmed immunomodulatory activity, in complementary with the direct action of $\mathrm{AL}$ 
on inducing CCA cell apoptosis,would support the potential of AL for further clinical development for CCA control in patients with early and late stage CCA.

\section{Methods}

In vitro evaluation of the modulatory effects on cytokine release by PBMCs

\section{Preparation of stock solutions of test materials}

The stock solutions of the test materials were prepared and stored at $-20{ }^{\circ} \mathrm{C}$. The crude ethanolic extract of $\mathrm{AL}$ was dissolved with $50 \%(\mathrm{v} / \mathrm{v})$ ethanol in distilled water to obtain $5 \mathrm{mg} / \mathrm{ml}$ stock solution. $\beta$-Eudesmol and atractylodin were dissolved with $100 \%$ ethanol to obtain $5 \mathrm{mg} /$ $\mathrm{ml}$ stock solutions and further diluted with the complete medium (RPMI1640 supplemented with 10\% fetal bovine serum albumin). The final concentration of ethanol in the working solution was lower than $0.1 \%(\mathrm{v} / \mathrm{v})$.

\section{Isolation of PBMCs}

PBMCs were separated from blood samples within $6 \mathrm{~h}$ after collection using Ficoll-Paque ${ }^{\mathrm{rm}}$ (GE Healthcare, NJ, USA). In brief, the blood sample was diluted with $2 \mathrm{x}$ volume of $1 \mathrm{x}$ phosphate buffer saline (PBS, $\mathrm{pH} 7.4$ ) and carefully layered over an equal volume of Ficoll-paque ${ }^{\mathrm{Tm}}$ in a $15 \mathrm{ml}$-conical tube. The suspension was centrifuged $\left(400 \times \mathrm{g}, 30 \mathrm{~min}, 20^{\circ} \mathrm{C}\right)$ and the upper layer was aspirated, leaving the mononuclear cell layer (lymphocytes, monocytes, and thrombocytes) undisturbed at the interphase. The mononuclear cell layer was transferred to a new conical tube, and $1 \mathrm{x}$ PBS was added. The supernatant was carefully removed following centrifugation $(300 \times$ g, $10 \mathrm{~min}, 20^{\circ} \mathrm{C}$ ). Cell pellets were resuspended with $1 \times$ PBS. Following centrifugation $\left(200 \times \mathrm{g}, 10 \mathrm{~min}, 20^{\circ} \mathrm{C}\right)$, the supernatant was carefully removed. The PBMC pellets were obtained through centrifugation over FicollPaque $^{\mathrm{m} x}$ cushions of buffy-coat, and cell number was counted using a cell counter. Cell suspension at a density of $5 \times 10^{6}$ cells $/ \mathrm{ml}$ was prepared in complete medium and incubated at $37^{\circ} \mathrm{C}$ for $3 \mathrm{~h}$.

\section{Cytotoxic activity on PBMCs}

PBMCs $\left(100 \mu \mathrm{l}\right.$ of $2 \times 10^{5}$ cells/well $)$ were seeded onto a 96-well plate. Each test material was dissolved in complete medium. The final concentrations of the AL extract, $\beta$-eudesmol, and atractylodin were 500, 250, $125,62.5,31.25,15.62,7.81$, and $3.95 \mu \mathrm{g} / \mathrm{ml}$ in the total volume of $100 \mu \mathrm{l} /$ well. The plates were incubated at $37{ }^{\circ} \mathrm{C}$ under $5 \% \mathrm{CO}_{2}$ for $24 \mathrm{~h}$. Freshly prepared MTT [3(4,5-dimethylthiazol-2-yl)-2,5-diphenyl tetrazolium bromide] reagent $(5 \mathrm{mg}$ in $20 \mu \mathrm{l}$ PBS) was added into each well and further incubated for $4 \mathrm{~h}$. Finally, the supernatant was removed, and DMSO reagent $(100 \mu \mathrm{l})$ was added into each well with swirling to completely solubilize the formazan crystal. The absorbance was measured at $570 \mathrm{~nm}$ in a microplate reader (Vario skan flash, Thermo scientific, USA). The treated cells, untreated cells, and blank were assayed in triplicate for three times. The concentration-effect curve was analyzed, and the $\mathrm{IC}_{50}$ and $\mathrm{IC}_{5}$ (concentrations that inhibit cell growth by 50 and $5 \%$, respectively) were determined using Calcusyn version 1.1 (Biosoft, Cambridge, UK).

\section{Exposure of PBMCs to standardized AL extract, $\beta$-eudesmol, and atractylodin}

PBMCs $\left(2 \times 10^{6}\right.$ cells/well $)$ were seeded onto a 6-well plate and exposed to standardized AL extract, $\beta$ eudesmol, and atractylodin at the final concentrations of 40, 20 and $10 \mu \mathrm{g} / \mathrm{ml}$. Concanavalin A (ConA, $10 \mu \mathrm{g} / \mathrm{ml}$ ) and dexamethasone $(200 \mu \mathrm{M})$ were, respectively, used to induce and inhibit (positive control) cell inflammation. To investigate the combined effect of the three test materials, cells were exposed to the standardized AL extract, $\beta$-eudesmol, and atractylodin at the final concentrations of 40,20 and $10 \mu \mathrm{g} / \mathrm{ml}$, together with $10 \mu \mathrm{g} / \mathrm{ml}$ of ConA. The untreated cell served as a negative control. The plates were incubated at $37^{\circ} \mathrm{C}$ under $5 \% \mathrm{CO}_{2}$ for $24 \mathrm{~h}$, and the cells were collected through centrifugation at $250 \times \mathrm{g}$ for $10 \mathrm{~min}$. The experiment was repeated three times, triplicate each.

\section{Extraction of RNA}

The RNA content of the exposed PBMCs was extracted with TRIzol $^{\mathrm{Tw}}$ (ThermoFisher Scientific, MA, USA). Briefly, PBMCs were added with $50 \mu \mathrm{l}$ of chloroform and transferred to a homogenizer (Scilogex D500, CT, USA). The homogenate was mixed and centrifuged at $12,000 \times g$ for $15 \mathrm{~min}\left(4^{\circ} \mathrm{C}\right)$. The supernatant was separated and transferred to a new tube. Cold isopropanol $(200 \mu \mathrm{l})$ was added, mixed, and centrifuged at 12,000 $\mathrm{x} g$ for $15 \mathrm{~min}$ $\left(4^{\circ} \mathrm{C}\right)$. The remaining supernatant was discarded, and the RNA pellets were washed with $1 \mathrm{ml}$ of $100 \%$ cold ethanol and left to dryness. The RNA pellets were dissolved with $20 \mu \mathrm{l}$ of DEPC water, and total RNA content was measured at $260 \mathrm{~nm}$ by spectrophotometer (ThermoFisher Scientific, MA, USA).

\section{Synthesis of CDNA}

The cDNA was prepared using the SuperScript ${ }^{\circ}$ III First-Strand Synthesis System for RT-PCR according to the manufacturer's protocol. Briefly, $2 \mu \mathrm{l}$ of RNA from PBMCs $(500 \mathrm{ng} / \mathrm{ml}), 0.5 \mu \mathrm{l}$ of $50 \mu \mathrm{M}$ oligo (dT), and $10 \mu \mathrm{M}$ of dNTP mix were mixed and incubated at $65^{\circ} \mathrm{C}$ for $5 \mathrm{~min}$. The mixture was immediately plated on ice for at least $1 \mathrm{~min}$. The cDNA synthesis mixture was prepared by adding $2 \mu \mathrm{l}$ of $10 \mathrm{x}$ RT buffer, $4 \mu \mathrm{l}$ of $25 \mathrm{mM}$ $\mathrm{MgCl}_{2}, 2 \mu \mathrm{l}$ of $0.1 \mathrm{M} \mathrm{DTT}, 1 \mu \mathrm{l}$ of RNase OUT $(40 \mathrm{U} / \mu \mathrm{l})$, and $1 \mu \mathrm{l}$ of SuperScript ${ }^{\mathrm{Tw}}$ III RT $(200 \mathrm{U} / \mu \mathrm{l})$. Ten $\mu \mathrm{l}$ of the cDNA synthesis mixture was added into each RNA 
template and incubated at $50^{\circ} \mathrm{C}$ for $50 \mathrm{~min}$. The reaction was terminated by incubation at $85^{\circ} \mathrm{C}$ for $5 \mathrm{~min}$. RNase $\mathrm{H}(1 \mu \mathrm{l})$ was added into each tube and incubated at $37^{\circ} \mathrm{C}$ for $20 \mathrm{~min}$. The synthesized cDNA was stored at $-20^{\circ} \mathrm{C}$ until use.

\section{Quantification of mRNA expression of interleukin 6 (IL6) and tumor necrosis factor-alpha (TNFa)}

The levels of IL6 and TNF $\alpha$ were quantified using iTaq Universal SYBR ${ }^{\mathrm{mi}}$ Green Supermix (Bio-Rad Laboratories Inc., CA, USA). The mRNA expression level of IL6 and TNF $\alpha$ were normalized with glyceraldehyde-3-phosphate dehydrogenase (GAPDH). Amplification of CDNA was performed on Bio-Rad CFX (Bio-Rad, CA, USA) using the following sequences of IL6 and TNF $\alpha$ forward and reverse primers (Table 1). The real-time PCR conditions consisted of denaturing at $95^{\circ} \mathrm{C}$ for $10 \mathrm{~s}$, annealing at $60^{\circ} \mathrm{C}$ for $10 \mathrm{~s}$, and extension at $72^{\circ} \mathrm{C}$ for $20 \mathrm{~s}$ ( 49 cycles). Each analysis was performed in three independent experiments, triplicate each. The delta-delta $\mathrm{Ct}$ calculation for the relative quantification of the target gene was as follow:

$$
\begin{aligned}
& \Delta \mathrm{Ct}(1)=[\mathrm{Ct}(\mathrm{IL}-6 \text { or } \mathrm{TNF}-\alpha)-\mathrm{Ct}(\mathrm{GAPDH})] \\
& \Delta \mathrm{Ct}(2)=[\mathrm{Ct}(\text { control for } \mathrm{IL}-6 \text { or } \mathrm{TNF}-\alpha)
\end{aligned}
$$

- $\mathrm{Ct}$ (control for GAPDH)

$$
\Delta \Delta \mathrm{Ct}=\Delta \mathrm{Ct}(1)-\Delta \mathrm{Ct}(2)
$$

Relative expression $=2^{-\Delta \Delta \mathrm{Ct}}$

Where $\Delta \mathrm{Ct}(1)=$ delta $\mathrm{Ct}$ of unknown sample, $\Delta \mathrm{Ct}$ (2) = delta Ct of control, IL- 6 or TNF- $\alpha=$ target gene, and $\mathrm{GAPDH}=$ housekeeping gene.

\section{Ex vivo evaluation of the effects on cytokine production and immune cell activity Participants and study design}

The study was an open, randomized, double-blinded, placebo-controlled design, conducted at Clinical Research Center, Faculty of Medicine, Thammasat University. Approval of the study protocol was obtained from the Ethics Committee, Thammasat University. The written informed consent was obtained from all research participants. The study protocol including background and rationale of the study, methodology, information

Table 1 Primer sequences for the real-time PCR experiment

\begin{tabular}{lll}
\hline Gene name & Forward primer & Reverse primer \\
\hline IL-6 & GTACATCCTCGACGGCATC & AGCCACTGGTTCTGTGCCT \\
TNF- $a$ & TGCTTGTCCTCAGCCTCTT & ATGGGCTACAGGCTTGTCACT \\
GAPDH & TCAACGGATTTGGTCGTATT & CTGTGGTCATGAGTCCTTCC \\
\hline
\end{tabular}

about the results of non-clinical studies of AL from previous studies particularly the safety profile, as well as the risks and benefits of study participation was explained to all potential participants in details. A total of 48 healthy Thai participants (24 males and 24 females), aged between 20 and 45 years with body mass index (BMI) between 20 and $25 \mathrm{~kg} / \mathrm{m}^{2}$, who were non-smokers and non-alcohol drinkers and were residents of Bangkok or suburb areas were recruited into the study. The sample size included in the study was based principally on the primary pharmacokinetic outcome parameters. Additional inclusion criteria were (i) absence of acute or chronic diseases that could affect vital organ functions, (ii) no history of surgery within the past six months, (ii) no history of hypersensitivity reactions or idiosyncratic reactions to drugs or herbal products, (iv) no concurrent or history of administration of drugs or herbal products within the past two weeks (except antipyretic or antiemetic drugs), (v) no history or current drug abuse, (vi) ability to communicate (reading, writing, and speaking) effectively, and (vii) willing to give informed consent for study participation. Exclusion criteria included those with (i) clinical significant abnormality of physical examination, (ii) clinical significant abnormality of electrocardiograms (ECG) or chest $\mathrm{x}$-ray, (iii) pregnancy or lactation, (iv) blood tests positive for $\mathrm{HBsAg}, \mathrm{HCV}$, or HIV, (v) abnormality in blood coagulation or history or concurrent use of anticoagulants or antiplatelets, or (vi) participation in any other study in the past three months. The exclusion of each potential participant from the study was confirmed through medical and laboratory records and verbal explanation.

After obtaining written informed consent, clinical and laboratory investigations were carried out to confirm the eligibility of the research participants. These included physical examination, electrocardiogram (ECG) monitoring, chest $\mathrm{X}$-ray test, and laboratory investigations (hematology, serum biochemistry, blood coagulation, urinalysis, serology, and pregnancy status). Eligible participants were admitted to the ward at the Clinical Research Center, Faculty of Medicine, Thammasat University during the first two days of the pharmacokinetic study and returned for drug administration and follow up daily until 12 or 21 days, depending on the allocated drug regimens.

\section{Drug administration and blood sample collection}

Study participants were allocated to two groups (12 males and 12 females for each group) with equal age distribution [median (range) ages for group 1 and group 2 were $22.0(21.0-27.0)$ and $23.0(21.0-30.0)$ years, respectively] as follows: 
- Group 1: Participants were randomized (using a randomization table generated by the statististician) to receive a single oral dose of either $1000 \mathrm{mg}$ of capsule formulation of the standardized AL extract (9 capsules, $112.5 \mathrm{mg}$ each, Kaolaor Laboratories Co. Ltd.) or placebo at the ratio of 20:4 participants. EDTA blood samples (20 $\mathrm{ml}$ for each time point) were collected at 0, 24 (day 1), 48 (day 2) hours, and days 7 and 14 of dosing.

- Group 2: Participants were randomized to receive multiple oral doses of either $1000 \mathrm{mg}$ of capsule formulation of the standardized AL extract or placebo daily for 21 days at the ratio of 20:4 participants. Blood samples $(20 \mathrm{ml}$ for each time point) were collected at 0,24 (day 1 ), 48 (day 2) hours of the first dose on day 1 , and before dosing on days $7,14,21$, and 22 .

All capsules were taken at once with $200 \mathrm{ml}$ drinking water. No food was consumed, although alcohol-free and xanthine-free fluids (fluids that contain caffeine, which has been reported for anti-inflammatory and inhibitory effect on immune response) were permissible the night before the study. Participants were fasted for 2 $h$ after drug administration to avoid any interaction between food and drugs. No other drugs, except analgesic, antipyretic and anti-emetic drugs were allowed during the study period to avoid possible interference of the immunomodulatory activity of these concurrent medications with the study drug AL.

Three millilitres of blood were used for measurement of lymphocyte subpopulations, and $12 \mathrm{ml}$ were used for evaluation of the cytotoxic activity. Clotted blood ( $5 \mathrm{ml}$ ) samples were collected for the investigation of cytokine levels.

\section{Determination of cytokine levels}

Cytokine bead array (CBA) Th1/Th2/Th17 cytokine kit (BD Biosciences, USA) was used to measure the levels of the secreted cytokines in serum samples according to the manufacturer's protocols (duplicate for each sample). Cytokine standards (IL17A, IFNy, TNF $\alpha$, IL2, IL4, IL6, and IL10) were prepared by reconstituting human Th1/ Th2/Th17 cytokine standards in $0.2 \mathrm{ml}$ of assay diluent to prepare 10x bulk standards. The standards were diluted in the assay diluents to obtain the dilutions of $1: 2$, $1: 4,1: 8,1: 16,1: 32,1: 64,1: 128$, and 1:256. The suspension was mixed and used at $10 \mu \mathrm{l} /$ test, and $50 \mu \mathrm{l}$ of mixed beads were transferred to each assay tube. Each standard cytokine dilution or unknown sample $(50 \mu \mathrm{l})$ and PE Detection Reagent $(50 \mu \mathrm{l})$ were added. The mixture was incubated at room temperature for $3 \mathrm{~h}$ in the dark, and washed with wash buffer $(1 \mathrm{ml})$, and centrifuged at $200 \times g$ for $5 \mathrm{~min}$. Finally, the wash buffer
$(300 \mu \mathrm{l})$ was added for further flow cytometry analysis. Cytometer setup bead tube used for flow cytometer setup before sample analysis was prepared by adding $100 \mu \mathrm{l}$ of cytometer setup beads from the BD CBA kit and $400 \mu \mathrm{l}$ of wash-buffer and thoroughly mixed. The level of each cytokine was normalized with total white blood cell count of each subject.

\section{Measurement of T-lymphocyte subpopulations}

EDTA-blood samples were stained with BD Multitest 6color TBNK kit ${ }^{\mathrm{mu}}$ (lymphocyte subpopulations: B cells, $\mathrm{CD}^{+}$cytotoxic $\mathrm{T}$ lymphocytes, $\mathrm{CD} 4^{+} \mathrm{T}$-helper lymphocytes, and NK cells) and analyzed by Facsverse ${ }^{\mathrm{ru}}$ flow cytometer. Blood samples were stained with BD Multitest 6-color TBNK kit ${ }^{\mathrm{Ta}}$ (BD, Biosciences, USA). In brief, $20 \mu \mathrm{l}$ of BD Multitest 6 -color TBNK reagent was added into the bottom tube with $50 \mu \mathrm{l}$ of EDTA anticoagulated blood, gently mixed, and incubated for 15 min in the dark at room temperature $\left(25^{\circ} \mathrm{C}\right)$. Following incubation, $450 \mu \mathrm{l}$ of $1 \mathrm{xBD}$ FACS lysing solution (BD, Biosciences, USA) was added, gently mixed, and incubated for $15 \mathrm{~min}$ in the dark at room temperature. The number of immune cells was determined using flow cytometry (BD Pharmingen, NJ, USA). The number of all T-lymphocyte subpopulations was normalized with total white blood cell count of each subject.

\section{Investigation of cytotoxic activity of PBMCs}

The cytotoxic activity against the CCA cell line CL-6, of the PBMCs isolated from blood samples collected from healthy subjects after administration of AL extract and placebo in both groups were evaluated using flow cytometry-based NK cytotoxicity assay [14].

\section{Preparation of effector cell}

PBMCs were used as effector cells. The cells were separated from blood samples of healthy volunteers within 6 $\mathrm{h}$ after collection using histopaque-1077 (Sigma, St. Louis, USA) according to the manufacturer's instructions. Histopaque-1077 was added into a $50-\mathrm{ml}$ conical centrifuge tube and carefully layered with the whole blood samples. The samples were centrifuged at $400 \times \mathrm{g}$ for $30 \mathrm{~min}$ at room temperature. The opaque interface containing mononuclear cells was transferred to a clean conical centrifuge tube. The cells were washed twice by adding $10 \mathrm{ml}$ and $5 \mathrm{ml}$ of isotonic phosphate-buffered saline solution, followed by centrifugation at $250 \times \mathrm{g}$ for 10 min. The supernatant was discarded, and the cell pellets were resuspended with freezing media (90\% FBS and $10 \%$ DMSO), placed in a Nalgene Cryo $1{ }^{\circ} \mathrm{C}$ freezing container, frozen at $-80^{\circ} \mathrm{C}$, and then transferred to liquid nitrogen storage until use. The day prior to assay, cryopreserved PBMC samples were thawed quickly in a $37^{\circ} \mathrm{C}$ water bath, washed twice in complete RPMI-1640 
medium and cell number was counted. Samples were resuspended in complete medium containing AntibioticAntimycotic $(100 \mathrm{U} / \mathrm{ml})$ solution and were maintained in humidified conditions $\left(5 \% \mathrm{CO}_{2}, 37^{\circ} \mathrm{C}\right)$ in a $\mathrm{CO}_{2}$ incubator (HERA CELL 150i, Thermo Scientific, MA, USA) for $24 \mathrm{~h}$. The effector cells were stained with $0.05 \mu \mathrm{M}$ CAM in $10 \mathrm{ml}$ of complete medium for $30 \mathrm{~min}$. Cells were washed twice in complete medium and used in the flow cytometry-based NK cytotoxicity assay.

\section{Preparation of target cell}

The human CCA cell line CL-6 (a gift from Associate Professor Adisak Wongkajornsilp, Faculty of Medicine, Siriraj Hospital, Thailand) was used to evaluate the cytotoxic activity of the prepared PBMCs. The cell was cultured in complete medium containing AntibioticAntimycotic $(100 \mathrm{U} / \mathrm{ml})$ solution and maintained in humidified conditions $\left(5 \% \mathrm{CO}_{2}, 37^{\circ} \mathrm{C}\right)$ in a $\mathrm{CO}_{2}$ incubator (HERA CELL 150i, Thermo Scientific, MA, USA). The cultured cells of $80 \%$ confluence were harvested using $0.25 \%$ Trypsin-EDTA.

\section{Flow-cytometry-based NK cytotoxicity assay}

CAM-stained effector cells (PBMCs) were seeded in triplicate with a fixed number of unstained naive target cells (10,000/ well) onto a 96-well microtiter plate with 50:1 (E:T ratios). Additional wells were used for the assessment of spontaneous apoptosis (target cells only in $200 \mu \mathrm{l}$ of complete medium) and maximum target cell death (target cells only in $100 \mu \mathrm{l}$ of complete medium plus $100 \mu \mathrm{l}$ of $100 \%$ DMSO). The contents of each wellcontaining effector and target cells were incubated for 1 $\mathrm{h}$ at $37^{\circ} \mathrm{C}$ in a humidified incubator under a $5 \% \mathrm{CO}_{2}$ atmosphere. The mixed cells (in $200 \mu \mathrm{l}$ of complete medium) were transferred to a new tube and washed twice with PBS. Five to $10 \mathrm{~min}$ before the acquisition, $10 \mu \mathrm{l}$ of $1 \mu \mathrm{g} / \mathrm{ml}$ propidium iodide (PI) (Sigma-Aldrich, St. Louis, USA) was added to each tube. Flow cytometry was performed using a BD FACSVerse flow cytometer (BD Biosciences, San Jose, USA). At least 5000 target cells per sample were acquired in order to determine the lysis of target cells by flow cytometry. To calculate net lysis of target cells, the PI-positive target cells in medium alone was subtracted from that of each sample.

\section{Statistical analysis}

Statistical analysis was performed using SPSS for Windows Software version 12 (IBM, New York, USA). The nonparametric analysis was applied for non-normally distributed data. Quantitative data are summarized as median (range), and qualitative data are summarized as number and percentage (\%) values. Comparison of two independent quantitative variables was performed using the Mann-Whitney U test. Statistical significance level was set at $\alpha=0.05$ for all tests.

\section{Results}

In vitro evaluation of the modulatory effects on cytokine release by PBMCs

The cytotoxic effects, expressed as $\mathrm{IC}_{50}$ [median (range)], of the crude ethanolic extract of AL, atractylodin and $\beta$-eudesmol on PBMCs were 147.06 (121.12152.34), 134.31 (125.32-142.54) and 139.26 (125.87$150.22) \mu \mathrm{g} / \mathrm{ml}$, respectively. The corresponding $\mathrm{IC}_{5}$ values were 41.32 (38.33-43.01), 39.38 (38.32-42.28) and $40.66(38.71-42.04) \mu \mathrm{g} / \mathrm{ml}$, respectively. The highest concentration of $\mathrm{AL}$, atractylodin and $\beta$-eudesmol that resulted in $5 \%$ of cell growth inhibition $\left(\mathrm{IC}_{5}\right)$ of about $40 \mu \mathrm{g} / \mathrm{ml}$, and the two lower concentrations (20 and $10 \mu \mathrm{g} / \mathrm{ml}$ ) were therefore selected as the highest concentration used in further RNA analysis of TNFa and IL6 expression in PBMCs. AL extract at all concentrations except at the lowest concentration (induces TNF $\alpha$ expression) significantly inhibited both TNF $\alpha$ and IL6 expression in Con A-mediated inflammation in PBMCs with strong potency. $\beta$-Eudesmol at all concentrations significantly inhibited only IL6 expression with strong potency. Atractylodin at the lowest concentration significantly inhibited the expression of both cytokines, while the highest concentration significantly inhibited only IL6 expression (Table 2).

\section{Ex vivo investigation of the effects on cytokine production and immune cell activity}

Ex vivo investigation of the effects on cytokine production and immune cell activity was performed using blood samples collected from all 48 subjects at specifiedtime points. All subjects were healthy as verified by clinical and laboratory assessments (Supplementary file). The production of IL17A, IFN $\gamma$, TNF $\alpha$, IL2, IL4, IL4, and IL10 cytokines in serum samples (expressed as foldchange compared with baseline level) from healthy subjects following the administration of a single (group 1) and multiple (group 2) dosing of $1000 \mathrm{mg}$ standardized AL extract and placebo is summarized in Figs. 1 and 2, respectively. For a single oral dose, a trend of increasing cytokine production (compared with placebo) at $24 \mathrm{~h}$ of dosing was observed with IL17A, TNF $\alpha$, IL2, and IL4, while a trend of decreasing production was observed with IFN $\gamma$ and IL10. The level of IL6 was comparable between the two groups (Fig. 1). For multiple oral dosing, a trend of decreasing the production of all cytokines was observed at 24 and $48 \mathrm{~h}$ of dosing, but significant difference was found only with IL17A at $24 \mathrm{~h}$ of dosing. The production of most cytokines (IFN $\gamma$, TNF $\alpha$, IL6, and IL10) were increasing on days 7 and 14 (Fig. 2). 
Table 2 The immunomodulatory effects (expressed as fold-changes compared with untreated control) of AL extract, $\beta$-eudesmol, and atractylodin at the concentrations of 40,20 and $10 \mu \mathrm{g} / \mathrm{ml}$, on the expression levels of TNFa and IL6 in PBMCs compared with untreated control cells. Concanavalin A (Con A) alone $(10 \mu \mathrm{g} / \mathrm{ml})$ and dexamethasone $(200 \mu \mathrm{M})$ were used to stimulate and inhibit (positive control) the inflammatory process in PBMCs. Data are presented as median (range) values of three independent experiments (triplicate each)

\begin{tabular}{|c|c|c|}
\hline \multirow[t]{2}{*}{ Treatment } & \multicolumn{2}{|l|}{ Fold changes } \\
\hline & TNFa & IL6 \\
\hline Untreated cells & 1.00 & 1.00 \\
\hline Con A $(10 \mu \mathrm{g} / \mathrm{ml})$ & $2.19(1.99-2.23)$ & $1.02(0.99-1.05)$ \\
\hline Dexamethasone $(200 \mu \mathrm{m})+$ Con A $(10 \mu \mathrm{g} / \mathrm{ml})$ & $0.60(0.59-0.61)^{b}$ & $0.33(0.32-0.33)^{b}$ \\
\hline $\mathrm{AL}(40 \mu \mathrm{g} / \mathrm{ml})+$ Con $\mathrm{A}(10 \mu \mathrm{g} / \mathrm{ml})$ & $0.99(0.98-1.00)^{b}$ & $0.01(0.009-0.012)^{\mathrm{c}}$ \\
\hline $\mathrm{AL}(20 \mu \mathrm{g} / \mathrm{ml})+$ Con $\mathrm{A}(10 \mu \mathrm{g} / \mathrm{ml})$ & $1.65(1.60-1.67)^{c}$ & $0.12(0.11-0.12)^{a}$ \\
\hline AL $(10 \mu \mathrm{g} / \mathrm{ml})+$ Con $\mathrm{A}(10 \mu \mathrm{g} / \mathrm{ml})$ & $2.5(2.49-2.51)$ & $0.45(0.43-0.49)^{\mathrm{b}}$ \\
\hline$\beta$-eudesmol $(40 \mu \mathrm{g} / \mathrm{ml})+$ Con $\mathrm{A}(10 \mu \mathrm{g} / \mathrm{ml})$ & $2.26(2.24-2.27)$ & $0.35(0.34-0.36)^{b}$ \\
\hline$\beta$-eudesmol $(20 \mu \mathrm{g} / \mathrm{ml})+$ Con $A(10 \mu \mathrm{g} / \mathrm{ml})$ & $2.2(2.21-2.23)$ & $0.58(0.56-0.58)^{c}$ \\
\hline$\beta$-eudesmol $(10 \mu \mathrm{g} / \mathrm{ml})+$ Con $A(10 \mu \mathrm{g} / \mathrm{ml})$ & $2.45(2.31-2.54)$ & $0.70(0.69-0.71)^{c}$ \\
\hline Atractylodin $(40 \mu \mathrm{g} / \mathrm{ml})+$ Con A $(10 \mu \mathrm{g} / \mathrm{ml})$ & $3.46(3.20-3.54)$ & $0.77\left(0.74-0.80^{c}\right.$ \\
\hline Atractylodin $(20 \mu \mathrm{g} / \mathrm{ml})+$ Con A $(10 \mu \mathrm{g} / \mathrm{ml})$ & $1.96(1.91-2.11)$ & $1.94(1.90-2.00)^{\mathrm{d}}$ \\
\hline Atractylodin $(10 \mu \mathrm{g} / \mathrm{ml})+$ Con A $(10 \mu \mathrm{g} / \mathrm{ml})$ & $0.26(0.23-0.26)^{a}$ & $0.11(0.09-0.12)^{\mathrm{a}}$ \\
\hline
\end{tabular}

a Statistically significant difference with Con $A(P<0.0001$, Mann-Whitney $U$ test $)$

b Statistically significant difference with Con $A(P<0.001$, Mann-Whitney $U$ test)

' Statistically significant difference with Con $A(P<0.01$, Mann-Whitney $U$ test)

${ }^{d}$ Statistically significant difference with Con A $(P<0.05$, Mann-Whitney $U$ test)

The modulatory effects (expressed as fold-change compared to baseline) of AL on the production of various subtypes of lymphocyte subpopulations in blood samples from both groups of subjects are summarized in Figs. 3 and 4, respectively. For a single oral dose of AL, a significant increase in NK cells (compared with placebo) was observed at almost all time points (days 3, 7, and 14), while a trend of increasing in B cells was observed on days 1, 7, and 14 (Fig. 3). For multiple dosing, a significant increase in $\mathrm{CD} 4^{+}$was observed on days 7 and 23 , and a significant increase in $\mathrm{CD}^{+}$was observed on day 14 (Fig. 4).

The modulatory effect (expressed as fold-change compared to baseline) of AL on the cytotoxic activity of NK cells in PBMCs (E:T ratio, 50:1) against CL-6 cell obtained from healthy subjects following the administration of the standardized AL extract $(n=20)$ and placebo $(n=4)$ is summarized in Fig. $5(a, b)$. For a single dose, a trend of increasing (compared with placebo) in the cytotoxic activity of PBMCs at $24 \mathrm{~h}$ of dosing was observed (Fig. 5a). For multiple dosing, a trend of increasing in the cytotoxic activity of PBMCs was observed at $24 \mathrm{~h}$ but terminated at $48 \mathrm{~h}$ of dosing (Fig. $5 \mathrm{a}$ ).

\section{Discussion}

Inflammation is a protective response to eliminate harmful stimuli and immune cells are the major participants in this process [15]. During inflammation, bone marrowderived monocytes are recruited to the site and differentiate into macrophages [16]. Macrophages eliminate pathogens and antigens through phagocytosis and induce inflammatory responses by producing cytokines and enzymes such as TNFa, IL6, inducible nitric oxide synthase (iNOS), and cyclooxygenase-2 (COX2) [17]. Inflammatory cytokines are generally classified as proinflammatory (IL1, IL4, IL6, IL12, IL15, IL17, IL23, TNF $\alpha$, and IFN $\gamma$ ) or anti-inflammatory (IL10 and TGF $\beta$ ) $[18,19]$. TNF $\alpha$ and IL6 are pro-inflammatory cytokines that modulate the growth, differentiation and proliferation of various types of cells, including CCA [3]. IL6 activates the p38 and p44/42 MAPK pathway, leading to the downregulation of $\mathrm{p} 21^{\mathrm{WAF} / \mathrm{CIP} 1}$, a key gene regulator of cell cycle and anchorage-dependent cells growth [20]. Overexpression of IL6 reduces methylation of the EGFR promoter and enhances EGFR expression, leading to tumor growth promotion [21]. In addition, IL6 upregulates Mcl-1 (an apoptosis inhibitor) enhancing tumour cells survival by increasing expression of STAT3 [22]. TNF $\alpha$ induces immune response at tissue injury locations, and thus, the secretion of oxidative radicals such as hydroxyl radical, NO, and superoxide anion. These molecules are associated with aggressive development of CCA by causing DNA damage and inhibiting DNA repair proteins [23]. TNF $\alpha$ promotes CCA cell migration by upregulating the expression of the EMT markers S100A4, vimentin, and ZEB2 [24]. It is proposed that anti-TNF $\alpha$ therapy could be an effective approach for CCA [25]. IL6 [26] and TNFa [27] promote tumor 

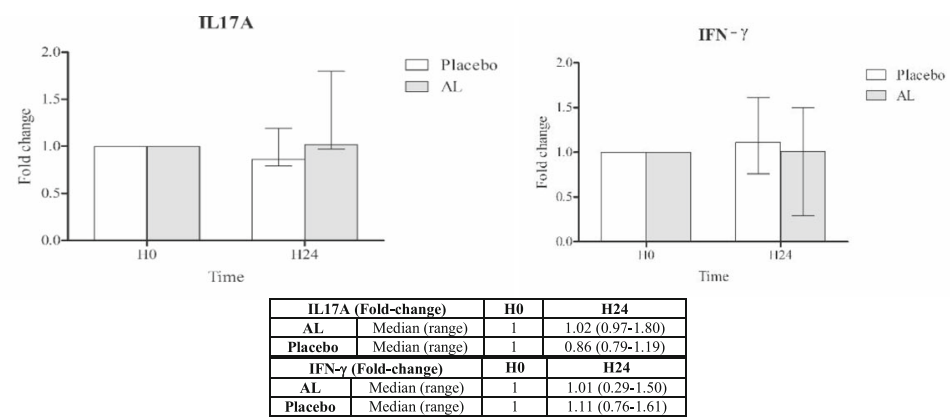

TNF- $\alpha$
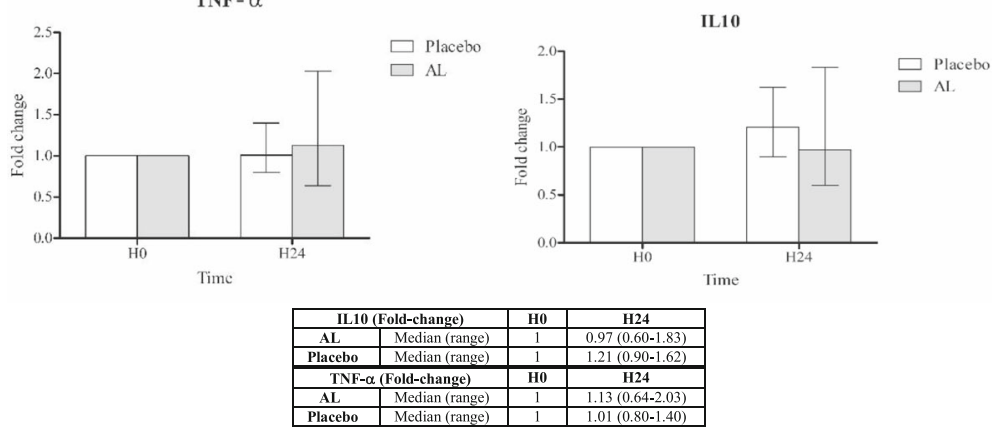

IL2

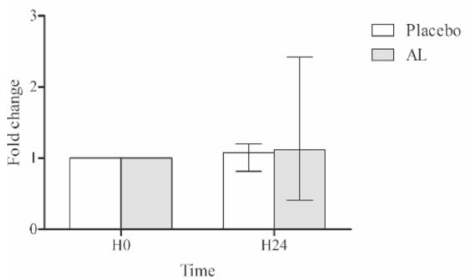

IL4

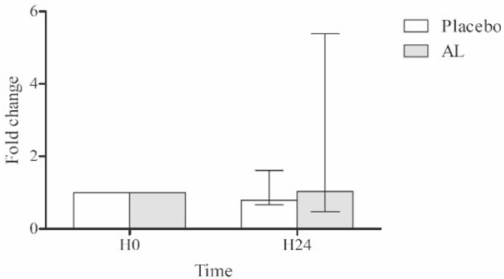

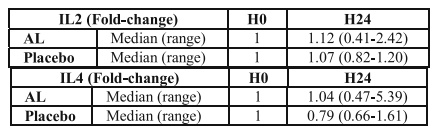

IL6
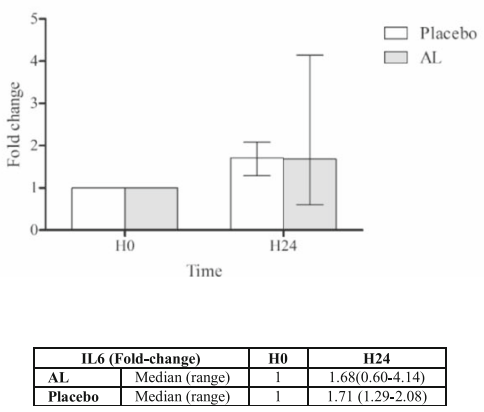

Fig. 1 Fold-changes of IL17A, IFNy, TNFa, IL2, IL4, IL6, and IL10 compared with baseline levels in healthy Thai subjects following the administration of a single oral dose of $1000 \mathrm{mg}$ of standardized AL extract $(n=20)$ and placebo $(n=4)$. Data are presented as median (range) values 


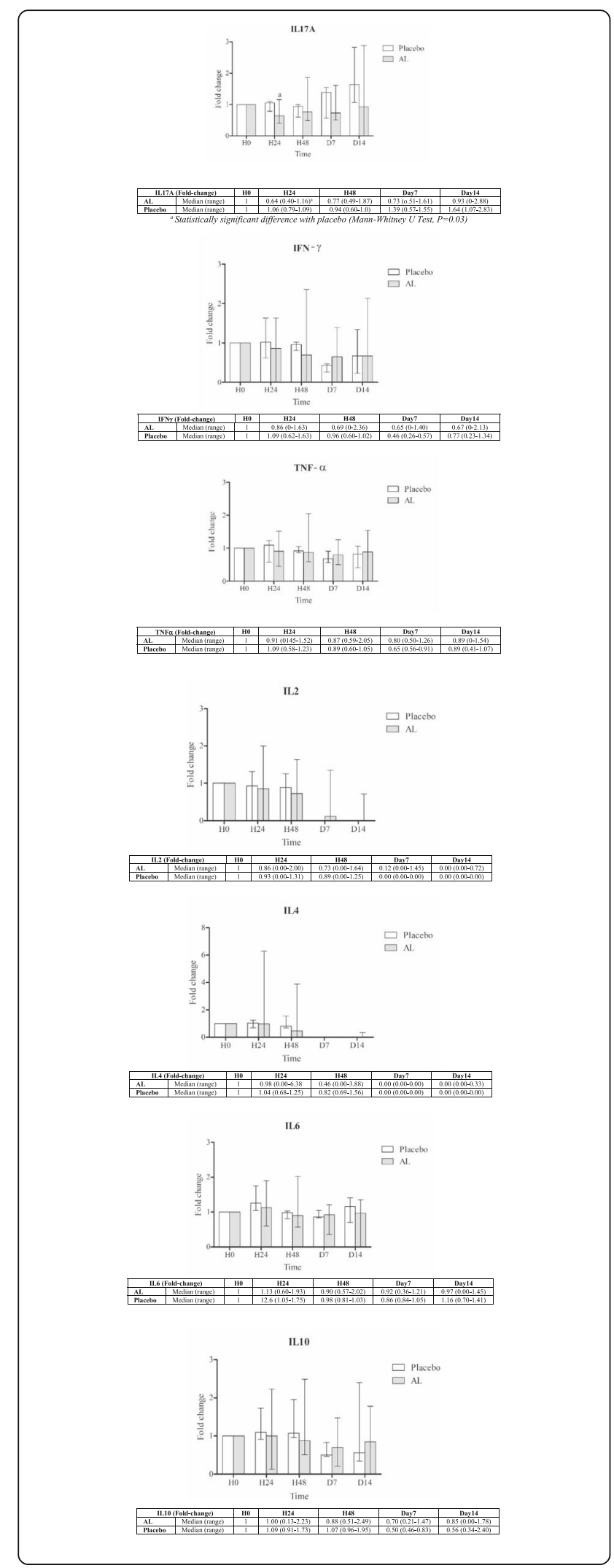

Fig. 2 Fold-changes of IL17A, IFNY, TNFa, IL2, IL4, IL6, and IL10 compared with baseline levels in healthy Thai subjects following the administration of daily oral doses of $1000 \mathrm{mg}$ standardized $\mathrm{AL}$ extract $(n=20)$ and placebo $(n=4)$. Data are presented as median (range) values

angiogenesis through increasing vascular endothelial growth factor (VEGF) expression. Increase in the production of both pro-inflammatory (IFN $\gamma$, IL1 $\beta$, IL2, IL4, IL5, IL6, IL8, IL12p70, TNF $\alpha$, and LT $\alpha$ ) and antiinflammatory (IL10) cytokines in PBMCs were reported in O. viverrini-associated human CCA compared to uninfected control [28]. In the present study, AL extract at all concentrations except the lowest concentration (induced TNF $\alpha$ expression) significantly inhibited both TNF $\alpha$ and IL6 expression in Con A-mediated inflammation in PBMCs with strong potency. $\beta$-Eudesmol at all concentrations significantly inhibited only IL6 expression with strong potency. Interestingly, the lowest concentration of atractylodin significantly inhibited the expression of both cytokines, while the highest concentration significantly inhibited only IL6 expression.

In a previous study, AL was shown to reduce the inflammatory mediators TNF $\alpha$ and IL6 [29]. Additionally, atractylodin was reported to reduce the production of TNF $\alpha$, IL1 $\beta$, IL4, IL6, and CSF2 [30] in the stimulated human mast cell (HMC-1). In the animal model, AL exerted antigastric ulcer activity through suppression the pro-inflammatory production mediators TNF $\alpha$, IL6, IL8, and prostaglandin E2 (PGE2) [29]. Other isolated compounds such as atractylenolide I, III, and atractylone were reported to exert anti-inflammatory activities. Atractylenolide I down-regulated the release of TNF $\alpha$, IL6, IL1 $\beta$, and IL13 [31]. The release of the proinflammatory cytokines stimulated by TSLP (TNF $\alpha$, IL6, and IL8) was also reduced by atractylenolide III [32]. Moreover, the compound also inhibited the release of NO, TNF $\alpha$, PGE2, and IL6 [33]. Atractylone reduced IL4 [34], IL6 [34, 35] and TNF $\alpha$ [35] levels. $\beta$-eudesmol was reported to inhibit the production and expression of IL6 through activation if p38 MAPK, NK- $\mathrm{kB}$ and caspase-1 in activated human mast cells [36]. Besides, it also reduced serum levels of histamine, IgE, IL1b, IL4, IL5, IL13 and VEGF in the passive anaphylaxis mouse model [37]. Altogether, the results of this study and previous studies suggested that the immunomodulatory effect of AL could be sum of the activity of each component in AL. Further analysis of the ex vivo immunomodulatory effect of AL was therefore performed in healthy subjects after oral administration of single or multiple doses of the standardized AL extract. Results indicated a trend of increasing of serum cytokine levels, i.e., TNF $\alpha$, IL2, IL4, and IL17A at $24 \mathrm{~h}$ after a single oral dose of $1000 \mathrm{mg} \mathrm{AL}$. A trend of decreasing cytokine 
CD4
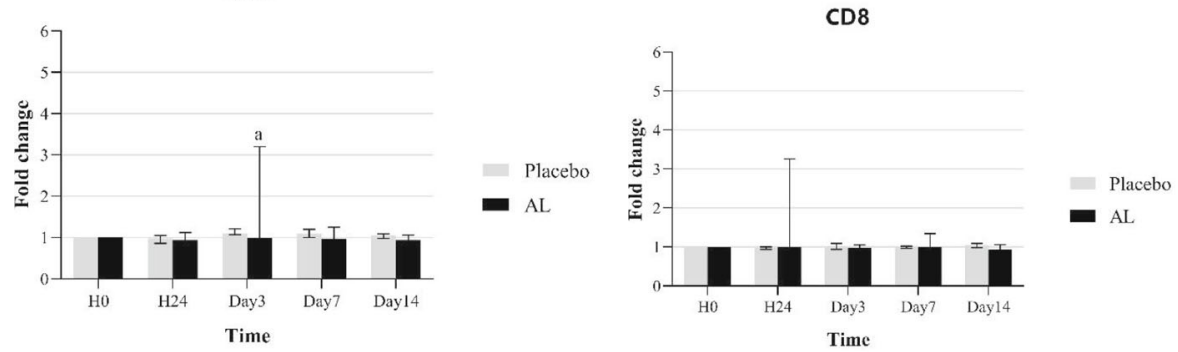

\begin{tabular}{|c|c|c|c|c|c|c|}
\hline \multicolumn{2}{|c|}{ CD8 (Fold-change) } & H0 & H24 & Day 3 & Day 7 & Day 14 \\
\hline AL & $\begin{array}{c}\text { Median } \\
\text { (range) }\end{array}$ & 1 & $\begin{array}{c}0.99 \\
(0.90-3.26)\end{array}$ & $\begin{array}{c}0.97 \\
(0.75-1.05\end{array}$ & $\begin{array}{c}0.99 \\
(0.84-1.34)\end{array}$ & $\begin{array}{c}0.94 \\
(0.72-1.06)\end{array}$ \\
\hline Placebo & $\begin{array}{c}\text { Median } \\
\text { (range) }\end{array}$ & 1 & $\begin{array}{c}0.97 \\
(0.94-1.00)\end{array}$ & $\begin{array}{c}1.00 \\
(0.94-1.09)\end{array}$ & $\begin{array}{c}1.00 \\
(0.96-1.06)\end{array}$ & $\begin{array}{c}1.05 \\
(0.98-1.09)\end{array}$ \\
\hline
\end{tabular}
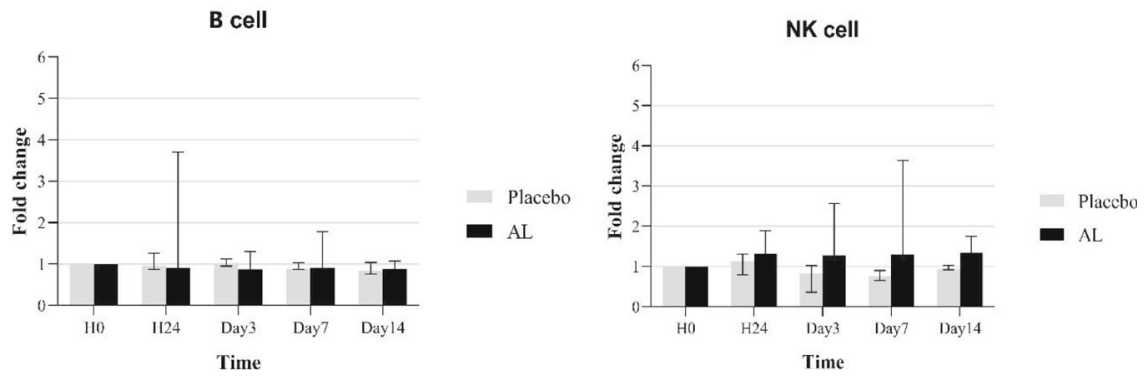

\begin{tabular}{|l|c|c|c|c|c|c|}
\hline $\begin{array}{l}\text { B cells } \\
\text { (Fold-change) }\end{array}$ & H0 & H24 & Day3 & Day7 & Day14 \\
\hline AL & $\begin{array}{l}\text { Median } \\
\text { (range) }\end{array}$ & 1 & $\begin{array}{c}0.90 \\
(0.66-3.70)\end{array}$ & $\begin{array}{c}0.87 \\
(047-1.30)\end{array}$ & $\begin{array}{c}0.90 \\
(0.74-1.78)\end{array}$ & $\begin{array}{c}0.88 \\
(0.74-1.07)\end{array}$ \\
\hline Placebo & $\begin{array}{l}\text { Median } \\
\text { (range) }\end{array}$ & 1 & $\begin{array}{c}0.96 \\
(0.87-1.26)\end{array}$ & $\begin{array}{c}0.99 \\
(0.95-1.12)\end{array}$ & $\begin{array}{c}0.89 \\
(0.87-1.03)\end{array}$ & $\begin{array}{c}0.84 \\
(0.76-1.04)\end{array}$ \\
\hline
\end{tabular}

\begin{tabular}{|l|l|c|c|c|c|c|}
\hline \multicolumn{2}{|l|}{$\begin{array}{l}\text { NK cells } \\
\text { (Fold-change) }\end{array}$} & H0 & H24 & Day3 & Day7 & Day14 \\
\hline AL & $\begin{array}{l}\text { Median } \\
\text { (range) }\end{array}$ & 1 & $\begin{array}{c}1.31 \\
(0.71-1.89)\end{array}$ & $\begin{array}{c}1.28 \\
(0.22-2.57)\end{array}$ & $\begin{array}{c}1.30 \\
(0.32-3.64)^{\mathbf{b}}\end{array}$ & $\begin{array}{c}1.34 \\
(0.21-1.75)\end{array}$ \\
\hline Placebo & $\begin{array}{l}\text { Median } \\
\text { (range) }\end{array}$ & 1 & $\begin{array}{c}1.14 \\
(0.79-1.31)\end{array}$ & $\begin{array}{c}0.83 \\
(0.36-1.02)\end{array}$ & $\begin{array}{c}0.76 \\
(0.65-0.90)\end{array}$ & $\begin{array}{c}0.94 \\
(0.92-1.03)\end{array}$ \\
\hline
\end{tabular}

Fig. 3 Fold-changes of $\mathrm{CD}^{+}, \mathrm{CD}^{+}, \mathrm{B}$ and NK cells compared with baseline levels in blood samples from healthy Thai subjects following the administration of a single oral dose of $1000 \mathrm{mg}$ standardized AL extract $(n=16)$ and placebo $(n=4)$. Data are presented as median (range) values

production was, on the other hand, observed with IFNY and IL10. For multiple oral dosing, a trend of decreasing in the production of all cytokines was observed at 24 and $48 \mathrm{~h}$ of dosing, but significant difference was found only with IL17A at $24 \mathrm{~h}$ of dosing. On days 7 and 14, the production of most cytokines (IFN $\gamma$, TNF $\alpha$, IL6, and IL10) were increasing. IL17A is a pro-inflammatory cytokine secreted from activated T-helper cell known as T-helper 17 cell [38]. IL17A ${ }^{+}$cell was found in CCA intratumoral areas which was correlated with lymph node metastasis, intrahepatic metastasis, and tumor progression to advanced stages [39]. The univariate analyses showed that the increase of $\mathrm{IL}_{17 \mathrm{~A}}{ }^{+}$cells in CCA intratumoral was significantly associated with the shortening of patients' survival [39]. Plasma concentrations of IL17A were found to be 2.5 -fold higher in patients with CCA and long-term liver fluke infection than in patients with liver fluke infection without CCA and healthy control (21-fold higher) [40]. In support of these previous reports, our result showed that IL17A level was significantly decreased at $24 \mathrm{~h}$ in subjects receiving multiple doses of AL, compared with placebo. Apart from IL17A, IL10 level appeared to be increased on days 7 and 14 of dosing. IL10 is strongly immunosuppressive cytokines. It not only induces anergy in $\mathrm{T}$ cells, but also inhibits the activation of inflammatory reactions by mast cells and 


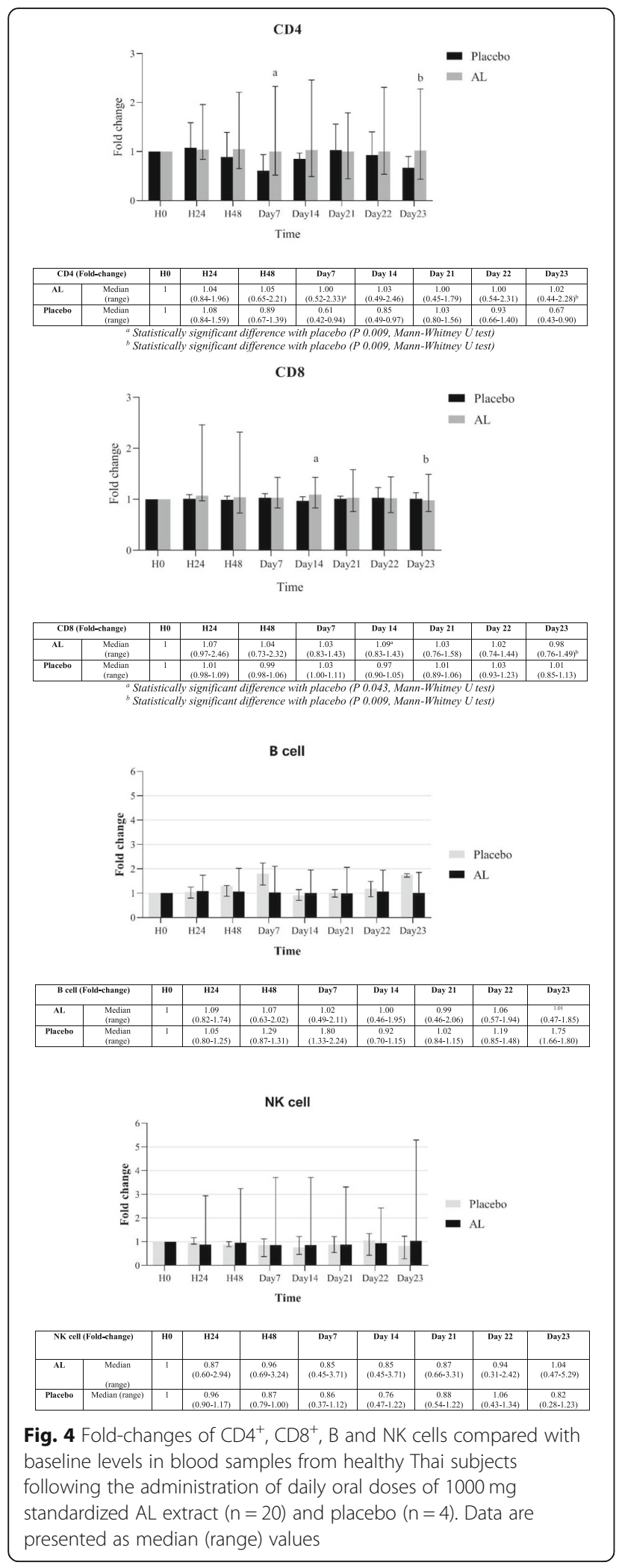

eosinophils [41]. Tumor-associated Tregs secretes IL10 and TGF- $\beta$, which inhibit cytotoxic T cells and NK cells and shape-up an immunosuppressive milieu [42, 43]. High Treg cell frequency is speculated to reflect a poor prognosis in pancreatic and colon cancer patients [44]. Moreover, IL10 was shown to exert antitumoral activity in gliomas, melanomas, and breast and ovarian carcinomas [45]. Atractylenolide I was reported to enhance IL10 expression in LPS-induced acute lung injury mouse model [31].

Results from earlier studies proposed IFN $\gamma$ as a prototypical antitumor cytokine. Results from subsequent studies however, supported its role in controlling tumor initiation and progression and in promoting the immunoevasive property. IFN $\gamma$ pretreatment potentiated lung colonization of intravenously inoculated B16 melanoma due to upregulation of MHC class I molecules on tumor cells and decreased sensitivity to NK cells [46]. In the in vivo study, increasing of metastatic potential was also attributed to the increased resistance to NK cells in IFNY gene-transfected TS/A mammary adenocarcinoma cells [47]. Moreover, obstruction of bile ducts was shown to be triggered by IFNY [48]. In the present study, no significant effects of $\mathrm{AL}$ on the production of IFN $\gamma$ as well as IL2, IL4, IL6, and IL10, TNF $\alpha$ were found. This could be due to the normal health condition of the volunteers included in the study. Unlike the in vitro condition of which the production of cytokines was limited to only PBMCs, serum cytokine levels in reflecting the overall systemic cytokine production from several cell types [49]. Cytokine detection in the supernatant of cultured PBMCs, therefore provides more specific cytokine expression from the immune cell, especially the mononuclear cells, which plays a central role in immune response [28]. Furthermore, due to large interindividual variability in serum level of each cytokine, statistical significance was not reached. Further large-scale studies in CCA patients are needed to substantiate the immunomodulatory role of AL.

NK cells can sense and respond to 'stressed' cells, such as cancer cells, in the nearby area [50]. Lysis of target cells, including neoplastic cells, is the hallmark function of NK cells and paramount importance for their tumorinhibiting efficacy [48]. After activation, NK cells secrete several cytokines such as IFN $\gamma$, TNF $\alpha$, granulocytemacrophage colony-stimulating factor (GM-CSF), and chemokines (CCL1, CCL2, CCL3, CCL4, CCL5, and CXCL8) that can modulate the function of other innate and adaptive immune cells [51]. Antitumor effects of NK cells can be overcome by various approaches, for examples, conservation of MHC class I (MHC-I) expression, shedding of ligands for the activating NK receptor (e.g., NKG2DLs), and secretion of immunomodulatory molecules (e.g., TGF- $\beta$, prostaglandin E2, and adenosine) 


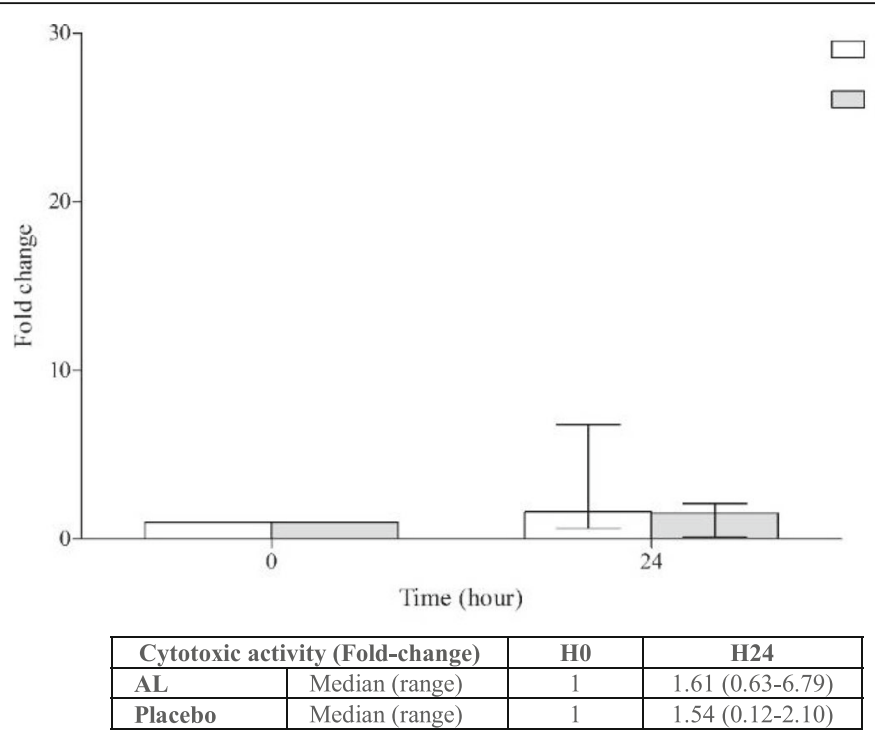

(a)

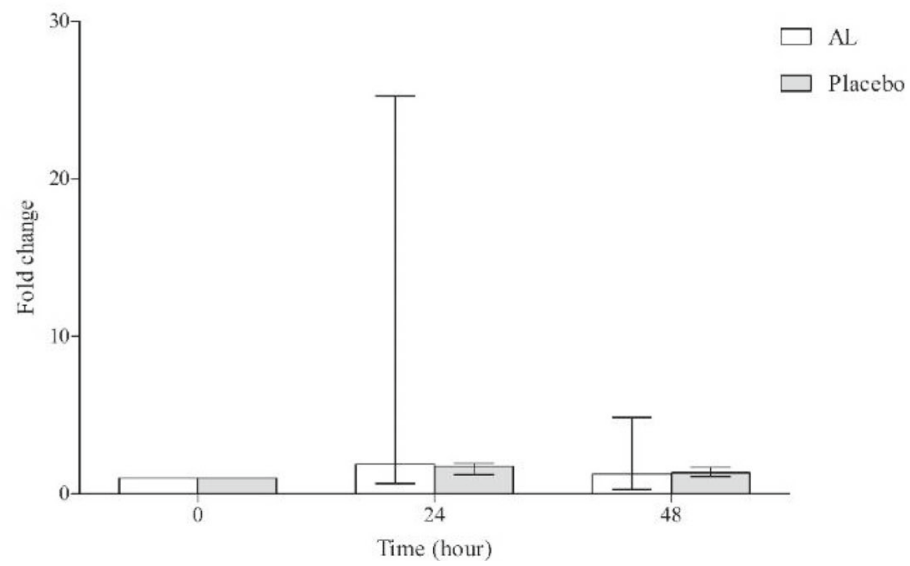

\begin{tabular}{|l|c|c|c|c|}
\hline \multicolumn{2}{|c|}{ Cytotoxic activity (Fold-change) } & H0 & H24 & H48 \\
\hline AL & Median (range) & 1 & $1.87(0.65-25.26)$ & $1.27(0.28-4.87)$ \\
\hline Placebo & Median (range) & 1 & $1.76(1.22-1.95)$ & $1.34(1.10-1 . .67)$ \\
\hline
\end{tabular}

(b)

Fig. 5 Fold-changes of cytotoxic activity of PBMCs against CL-6 cell compared with baseline levels in blood samples from healthy Thai subjects following the administration of (a) single oral dose of $1000 \mathrm{mg}$ and (b) multiple oral doses of 1000 of standardized AL extract for 21 days ( $n=20$ for $\mathrm{AL}$ and $\mathrm{n}=4$ for each group). Data are presented as median (range) values

by tumor cells, ultimately resulting in tumor progression [50]. Our study demonstrated a significant increase in NK cells at almost all observation time points (days 3, 7, and 14). Tumor-infiltrating lymphocytes (TILs) are highly heterogeneous population which include B lymphocytes, $\mathrm{CD}^{+}$cytotoxic $\mathrm{T}$ lymphocytes, cytokinesecreting $\mathrm{CD}^{+} \mathrm{T}$ helper lymphocytes, and Forkhead box
P3 (FoxP3) ${ }^{+}$Tregs [52]. In CCA, $\mathrm{CD}^{+}$and $\mathrm{CD}^{+}$cytotoxic $\mathrm{T}$ lymphocytes have been investigated with regard to their presence, locations within the tumor, and association with patients' survival. Multiple studies confirm that enhanced $\mathrm{CD}^{+}$and $\mathrm{CD}^{+}$infiltrates (also in combination with low numbers of macrophages) in CCA and extrahepatic biliary tract cancer are associated with 
improvement of overall survival, fewer lymph node metastases and reduced venous and perineural invasion [53-57], whereas small amounts of CD8 ${ }^{+}$TILs are associated with poor overall survival [58]. Total tumorinfiltrating B lymphocytes were shown to be correlated with a longer overall survival probability in biliary tract cancer [53]. In our study, significant increase in $\mathrm{CD} 4^{+}$in AL-treated subjects compared with placebo was observed on days 7 and 23, and a significant increase in $\mathrm{CD}^{+}$was observed on day 14 in subjects receiving multiple dosing of AL. Taken together, these results suggested that under normal conditions, oral administration of AL can stimulate the production of innate and adaptive immune cells.

The cytotoxic activity against CL- 6 cells of the NK cells in PBMCs appeared to be increased at $24 \mathrm{~h}$ of a single or multiple dosing of AL compared with placebo. The previous study reported that the co-culture of CCA cells with the epidermal growth factor receptor monoclonal antibody-- cetuximab, and NK cells significantly enhanced CCA cell death by potentiating antibodydependent cellular cytotoxicity [59]. Similarly, infusion of ex vivo expanded human NK cells into CCA xenograft mice resulted in inhibition of tumor growth [58]. Notably, among the CCA cell lines, ex vivo expanded human NK cells showed a higher cytolytic activity to HuCCT1 and SNU308, but lower activity in SNU1196 and SNU478 cells [60]. This suggested that NK cells display variable cytolytic effects depending on the various cancer types.

\section{Conclusion}

Results from the present study confirm the immunomodulatory activity of AL in humans. This activity, in complementary with the direct action of AL on inducing CCA cell apoptosis, suggests its potential role for CCA control. Further studies are underway to support the immunomodulatory activity in CCA patients.

\section{Supplementary Information}

The online version contains supplementary material available at https://doi. org/10.1186/s12906-020-03199-6.

\section{Additional file 1}

\footnotetext{
Abbreviations

AL: Atractylodes lancea (Thunb.) D.C; CAM: Calcein-AM; CBA: Cytometric bead array; CCA: Cholangiocarcinoma; CCL: Chemokine (C-C motif) ligand; CD: Cluster of differentiation; CDNA: Complementary deoxyribonucleic acid; Cl: Confidence interval; ConA: Concanavalin A; COX-2: Cyclooxygenase-2; CSF2: Colony stimulating factor-2; Ct: Cycle threshold; CXCL: Chemokine (CX-C motif) ligand; DEPC: Diethyl pyrocarbonate; DMSO: Dimethyl sulfoxide; dNTP: Deoxynucleoside triphosphate; DTT: Dithiothreitol; EDTA: Ethylenediaminetetraacetic acid; EGFR: Epidermal growth factor receptor; EMT: Epithelial-to-mesenchymal transition; E:T: Effector to target ratio; FBS: Fetal bovine serum; 5-FU: Fluorouracil; GAPDH: glyceraldehyde-3phosphate dehydrogenase; GM-CSF: Granulocyte-macrophage colony-
}

stimulating factor; HMC-1: Human mast cell line; $I C_{50}$ : The concentration that inhibits cell growth by 50\%; IFN-: Interferon-gamma; IL: Interleukin; iNOS: inducible nitric oxide synthase; LPS: Lipopolysaccharide; MAPK: Mitogen-activated protein kinase; Mcl-1: Myeloid cell leukemia-1; MHC: Major histocompatibility complex; mRNA: Messenger ribonucleic acid; MTT: 3-(4,5-dimethylthiazol-2-yl)-2,5-diphenyl tetrazolium bromide; NK: Natural killer; NKG2DL: Natural killer group 2, member D ligand; NO: Nitric oxide; NOS: Nitrous oxide systems; PBMC: Peripheral blood mononuclear cell; PBS: Phosphate buffer saline; PCR: Polymerase chain reaction; PGE2: Prostaglandin E2; PI: Propidium iodide; RNase: Ribonuclease; RPMI: Roswell park memorial institute; RT-PCR: Reverse transcription polymerase chain reaction; SD: Standard deviation; STAT-3: Signal transducer and activator of transcription-3; TAM: Tumor-associated macrophage; TGF- $\beta$ : Transforming growth factor-beta; Th1: T helper type 1; TIL: Tumorinfiltrating lymphocyte; TNFa: Tumor necrosis factor-alpha; Treg cell: Regulatory T cell; TS/A: Highly metastatic mouse mammary adenocarcinoma cell line; TSLP: Thymic stromal lymphopoietin; VEGF: Vascular endothelial growth factor; WBC: White blood cell; ZEB2: Zinc finger E-box binding homeobox-2

\section{Acknowledgements}

We would like to thank Associate Professor Mayuri Tarasuk, Dr. Kanawut Kotawong, Ms. Panida Kongjam, Ms. Nadda Muhamad, and Ms. Arthitaya Tiengsusuk for their assistance in sample collection and technical supports.

\section{Authors' contributions}

$K N, W C, T P$, and IK were involved in the design of the experimental study. IK, LP and SW performed all of the experiments and data analysis. IK drafted the manuscript. KN revised and finalized the manuscript. All authors reviewed and approved the final manuscript for submission.

\section{Funding}

The study was supported by Thammasat University (Center of Excellence in Pharmacology and Molecular Biology of Malaria and Cholangiocarcinoma), and National Research Council of Thailand. Kesara Na-Bangchang is supported by the National Research Council of Thailand under the Research Team Promotion grant (grant number 820/2563). Inthuon Kulma is supported by Thailand Research Fund under the Royal Golden Jubilee Ph.D. Program (grant number PHD/0096/2560).

\section{Availability of data and materials}

The datasets generated and/or analysed during the current study are available as supplementary file and additional data are available from the corresponding author on reasonable request.

\section{Ethics approval and consent to participate}

The clinical study protocol was approved by the Human research Ethics Committee of Thammasat University, Thailand (No. 019/2561). Written informed consents for study participation was obtained from all subjects before study.

\section{Consent for publication}

Not applicable.

\section{Competing interests}

The authors declare that they have no competing interests.

\section{Author details}

${ }^{1}$ Graduate Program in Bioclinical Sciences, Chulabhorn International College of Medicine, Thammasat University (Rangsit Campus), Pathumthani 12121, Thailand. ${ }^{2}$ Center of Excellence in Pharmacology and Molecular Biology of Malaria and Cholangiocarcinoma, Thammasat University (Rangsit Campus), Pathumthani 12121, Thailand. ${ }^{3}$ Drug Discovery and Development Center, Office of Advanced Science and Technology, Thammasat University (Rangsit Campus), Pathumthani 12121, Thailand. 
Received: 12 October 2020 Accepted: 28 December 2020 Published online: 12 February 2021

\section{References}

1. Khan SA, Tavolari S, Cholangiocarcinoma BG. Epidemiology and risk factors. Liver Int. 2019;39(Suppl 1):19-31.

2. Andersen JB. Molecular pathogenesis of intrahepatic cholangiocarcinoma. J Hepatobiliary Pancreat Sci. 2015;22(2):101-13.

3. Pinto C, Giordano DM, Maroni L, Marzioni M. Role of inflammation and proinflammatory cytokines in cholangiocyte pathophysiology. Biochim Biophys Acta Mol Basis Dis. 2018;1864(4 Pt B):1270-8.

4. Hasita H, Komohara Y, Okabe H, Masuda T, Ohnishi K, Lei XF, Beppu T, Baba $\mathrm{H}$, Takeya M. Significance of alternatively activated macrophages in patients with intrahepatic cholangiocarcinoma. Cancer Sci. 2010;101(8):1913-9.

5. Koca YS, Bulbul M, Barut I. The Diagnostic Roles of Cytokines in Hepatobiliary Cancers. Biomed Res Int. 2017;2979307:1-5.

6. Chen Z, Guo P, Xie X, Yu H, Wang Y, Chen G. The role of tumour microenvironment: a new vision for cholangiocarcinoma. J Cell Mol Med. 2019:23(1):59-69.

7. Brivio $S$, Cadamuro M, Strazzabosco M, Fabris L. Tumor reactive stroma in cholangiocarcinoma: The fuel behind cancer aggressiveness. World J Hepatol. 2017;9(9):455-68.

8. Loilome W, Bungkanjana P, Techasen A, Namwat N, Yongvanit P, Puapairoj A, Khuntikeo N, Riggins GJ. Activated macrophages promote Wnt/betacatenin signaling in cholangiocarcinoma cells. J Inter Soc Oncodevelop. Biol Med. 2014:35(6):5357-67.

9. Na-Bangchang K, Plengsuriyakarn T, Karbwang J. Research and Development of Atractylodes lancea (Thunb) DC. as a Promising Candidate for Cholangiocarcinoma Chemotherapeutics. Evid Based Complement Alternat Med. 2017;5929234:1-16.

10. Kotawong K, Chaijaroenkul W, Muhamad P, Na-Bangchang K. Cytotoxic activities and effects of atractylodin and $\beta$-eudesmol on the cell cycle arrest and apoptosis on cholangiocarcinoma cell line. J Pharmacol Sci. 2018;136(2): 51-6.

11. Mathema VB, Chaijaroenkul W, Na-Bangchang K. Cytotoxic activity and molecular targets of atractylodin in cholangiocarcinoma cells. J Pharm Pharmacol. 2019;71(2):185-95.

12. Mathema VB, Chaijaroenkul W, Karbwang J, Na-Bangchang K. Growth inhibitory effect of $\beta$-eudesmol on cholangiocarcinoma cells and its potential suppressive effect on heme oxygenase-1 production, STAT1/3 activation, and NF-kB downregulation. Clin Exp Pharmacol Physiol. 2017; 44(11):1145-54.

13. Jun $X$, Fu P, Lei $Y$, Cheng P. Pharmacological effects of medicinal components of Atractylodes lancea (Thunb.) DC. Chin Med. 2018;13:59.

14. Jang YY, Cho D, Kim SK, Shin DJ, Park MH, Lee JJ, Shin MG, Shin JH, Suh SP, Ryang DW. An improved flow cytometry-based natural killer cytotoxicity assay involving calcein AM staining of effector cells. Ann Clin Lab Sci. 2012; 42(1):42-9.

15. Medzhitov R. Inflammation 2010: new adventures of an old flame. Cell. 2010;140(6):771-6.

16. Sprangers S, de Vries TJ, Everts V. Monocyte Heterogeneity: Consequences for Monocyte-Derived Immune Cells. J Immunol Res. 2016;1475435:1-10 https://doi.org/10.1155/2016/1475435.

17. Kwak T-K, Jang H-S, Lee M-G, Jung Y-S, Kim D-O, Kim Y-B, Kim J-I, Kang H. Effect of Orally Administered Atractylodes macrocephala, Koidz Water Extract on Macrophage and T Cell Inflammatory Response in Mice. Evid Based Compl Alt Med. 2018;2018:4041873.

18. Inclan-Rico JM, Siracusa MC. First Responders: Innate Immunity to Helminths. Trends Parasitol. 2018;34(10):861-80.

19. Landskron G, De la Fuente M, Thuwajit P, Thuwajit C, Hermoso MA. Chronic inflammation and cytokines in the tumor microenvironment. J Immunol Res. 2014;149185:1-19 https://doi.org/10.1155/2014/149185.

20. Tadlock L, Patel T. Involvement of p38 mitogen-activated protein kinase signaling in transformed growth of a cholangiocarcinoma cell line. Hepatology. 2001;33(1):43-51

21. Wehbe H, Henson R, Meng F, Mize-Berge J, Patel T. Interleukin-6 contributes to growth in cholangiocarcinoma cells by aberrant promoter methylation and gene expression. Cancer Res. 2006;66(21):10517-24.

22. Isomoto H, Kobayashi S, Werneburg NW, Bronk SF, Guicciardi ME, Frank DA, Gores GJ. Interleukin 6 upregulates myeloid cell leukemia-1 expression through a STAT3 pathway in cholangiocarcinoma cells. Hepatology. 2005; 42(6):1329-38.

23. Jaiswal M, LaRusso N, Burgart L, Gores G. Inflammatory Cytokines Induce DNA damage and Inhibit DNA repair in Cholangiocarcinoma Cells by a Nitric Oxide-dependent Mechanism1. Can Res. 2000;60:21-32.

24. Techasen A, Namwat N, Loilome W, Duangkumpha K, Puapairoj A, Saya H, Yongvanit $\mathrm{P}$. Tumor necrosis factor-alpha modulates epithelial mesenchymal transition mediators ZEB2 and S100A4 to promote cholangiocarcinoma progression. J Hepatobiliary Pancreat Sci. 2014;21(9): 703-11.

25. Utaisincharoen $P$, Tangthawornchaikul N, Ubol S, Chaisuriya P, Sirisinha S. Tnf-a induces caspase 3 (CPP 32) dependent apoptosis in human cholangiocarcinoma cell line. Southeast Asian J Trop Med Public Hlth. 2000; 31(Suppl 1):167-70.

26. Feurino LW, Zhang Y, Bharadwaj U, Zhang R, Li F, Fisher WE, Brunicardi FC, Chen C, Yao Q, Min L. IL-6 stimulates Th2 type cytokine secretion and upregulates VEGF and NRP-1 expression in pancreatic cancer cells. Cancer Biol Ther. 2007;6(7):1096-100

27. Yoshida $S$, Ono M, Shono $T$, Izumi $H$, Ishibashi $T$, Suzuki $H$, Kuwano M. Involvement of Interleukin-8, Vascular Endothelial Growth Factor, and Basic Fibroblast Growth Factor in Tumor Necrosis Factor Alpha-Dependent Angiogenesis. Mol Cell Biol. 1997;17:4015-23.

28. Surapaitoon A, Suttiprapa S, Khuntikeo N, Pairojkul C, Sripa B. Cytokine profiles in Opisthorchis viverrini stimulated peripheral blood mononuclear cells from cholangiocarcinoma patients. Parasitol Int. 2017;66(1):889-92.

29. Yu Y, Jia T-Z, Cai Q. Comparison of anti-inflammatory activity between crude Atractylodes lancea and their processed products by stir-baking with bran in rat models of gastric ulcer. Zhongguo Zhong Yao Za Zhi. 2016;41(4): 705-10

30. $Y u$ C, Xiong $Y$, Chen D, Li Y, Xu B, Lin Y, Tang Z, Jiang C, Wang L. Ameliorative effects of atractylodin on intestinal inflammation and cooccurring dysmotility in both constipation and diarrhea prominent rats. Korean J Physiol Pharmacol. 2017;21(1):1-9.

31. J-I Z, W-m H, Q-y Z. Atractylenolide I protects mice from lipopolysaccharideinduced acute lung injury. Eur J Pharmacol. 2015;765:94-9.

32. Yoou MS, Nam SY, Jin MH, Lee SY, Kim MS, Roh SS, Choi IH, Woo N, Lim S, Kim DH, et al. Ameliorative effect of atractylenolide III in the mast cell proliferation induced by TSLP. Food Chem Toxicol. 2017;106(Pt A):78-85

33. Ji GQ, Chen RQ, Wang L. Anti-inflammatory activity of atractylenolide III through inhibition of nuclear factor-kappaB and mitogen-activated protein kinase pathways in mouse macrophages. Immunopharmacol Immunotoxicol. 2016;38(2):98-102.

34. Kim HY, Nam SY, Hwang SY, Kim HM, Jeong HJ. Atractylone, an active constituent of KMP6, attenuates allergic inflammation on allergic rhinitis in vitro and in vivo models. Mol Immunol. 2016;78:121-32.

35. Cheng Y, Mai JY, Hou TL, Ping J, Chen JJ. Antiviral activities of atractylon from Atractylodis Rhizoma. Mol Med Rep. 2016;14(4):3704-10.

36. Seo M, Kim SJ, Kang TH, Rim HK, Jeong HG, Um JY, Kim HM. The regulatory mechanism of beta-eudesmol is through the suppression of caspase-1 activation in mast cell-mediated imflammatory response. Immunolpharmacol Immunoltoxicol. 2011:33(1):178-85.

37. Han NR, Moon PD, Ryu KJ, Jang JB, Kim HM, Jeong HJ. Beta-eudesmol suppresses allergic reactions via inhibiting mast cell degranulation. Clin Exp Pharmacol Physiol. 2017;44(2):257-65.

38. Gu C, Wu L, Li X. IL-17 family. cytokines, receptors and signaling. Cytokine. 2013;64(2):477-85

39. Gu FM, Gao Q, Shi GM, Zhang $X$, Wang J, Jiang JH, Wang XY, Shi YH, Ding ZB, Fan J, et al. Intratumoral IL-17(+) cells and neutrophils show strong prognostic significance in intrahepatic cholangiocarcinoma. Ann Surg Oncol. 2012;19(8):2506-14

40. Su SB, Zhang JF, Huang FF, Cen Y, Jiang HX. Large numbers of interleukins22- and -17A-producing $T$ helper cells in cholangiocarcinoma related to liver fluke infection. Microbiol Immunol. 2017;61(8):345-54.

41. Akdis C, Blaser K. Mechanisms of interleukin-10-mediated immune suppression. Immunol. 2001;103:131-6.

42. Vivier E, Ugolini S, Blaise D, Chabannon C, Brossay L. Targeting natural killer cells and natural killer T cells in cancer. Nat Rev Immunol. 2012;12(4):239-52.

43. Hiraoka N, Onozato K, Kosuge T, Hirohashi S. Prevalence of FOXP3+ regulatory $T$ cells increases during the progression of pancreatic ductal adenocarcinoma and its premalignant lesions. Clin Cancer Res. 2006;12(18): 5423-34. 
44. Suzuki H, Chikazawa N, Tasaka T, Wada J, Yamasaki A, Kitaura Y, Sozaki M, Tanaka M, Onishi H, Morisaki T, et al. Intratumoral CD8+ T/FOXP3+ cell ratio is a predictive marker for survival in patients with colorectal cancer. Cancer Immunol Immunother. 2010:59(5):653-61.

45. Lin WW, Karin M. A cytokine-mediated link between innate immunity, inflammation, and cancer. J Clin Invest. 2007;117(5):1175-83.

46. Taniguchi K, Petersson M, Hoglund P, Kiessling R, Klein G, Karre K. Interferon gamma induces lung colonization by intravenously inoculated B16 melanoma cells in parallel with enhanced expression of class I major histocompatibility complex antigens. Proc Natl Acad Sci USA. 1987;84(10): 3405-9.

47. Lollini PL, Bosco MC, Cavallo F, De Giovanni C, Giovarelli M, Landuzzi L, Musiani P, Modesti A, Nicoletti G, Palmieri G, et al. Inhibition of tumor growth and enhancement of metastasis after transfection of the gammainterferon gene. Int J Cancer. 1993;55(2):320-9.

48. Shivakumar P, Campbell KM, Sabla GE, Miethke A, Tiao G, McNeal MM, Ward $R L$, Bezerra JA. Obstruction of extrahepatic bile ducts by lymphocytes is regulated by IFN- $\gamma$ in experimental biliary atresia. J Clin Invest. 2004;114(3): 322-9.

49. Lippitz BE. Cytokine patterns in patients with cancer: a systematic review. Lancet Oncol. 2013;14(6):e218-28.

50. Morvan MG, Lanier LL. NK cells and cancer: you can teach innate cells new tricks. Nat Rev Cancer. 2016;16(1):7-19.

51. Paul S, Lal G. The Molecular Mechanism of Natural Killer Cells Function and Its Importance in Cancer Immunotherapy. Front Immunol. 2017;8(1124):2332.

52. Fabris L, Perugorria MJ, Mertens J, Bjorkstrom NK, Cramer T, Lleo A, Solinas A, Sanger $\mathrm{H}$, Lukacs-Kornek V, Moncsek A, et al. The tumour microenvironment and immune milieu of cholangiocarcinoma. Liver Int. 2019;39(Suppl 1):63-78.

53. Goeppert B, Frauenschuh L, Zucknick M, Stenzinger A, Andrulis M, Klauschen F, Joehrens K, Warth A, Renner M, Mehrabi A, et al. Prognostic impact of tumour-infiltrating immune cells on biliary tract cancer. $\mathrm{Br}$ J Cancer. 2013;109(10):2665-74.

54. Oshikiri T, Miyamoto M, Shichinohe T, Suzuoki M, Hiraoka K, Nakakubo Y, Shinohara T, Itoh T, Kondo S, Katoh H. Prognostic value of intratumoral CD8+ T lymphocyte in extrahepatic bile duct carcinoma as essential immune response. J Surg Oncol. 2003;84(4):224-8.

55. Miura T, Yoshizawa T, Hirai H, Seino H, Morohashi S, Wu Y, Wakiya T, Kimura N, Kudo D, Ishido K, et al. Prognostic Impact of CD163+ Macrophages in Tumor Stroma and CD8+ T-Cells in Cancer Cell Nests in Invasive Extrahepatic Bile Duct Cancer. Anticancer Res. 2017;37(1):183-90.

56. Takagi S, Miyagawa S, Ichikawa E, Soeda J, Miwa S, Miyagawa Y, lijima S, Noike T, Kobayashi A, Kawasaki S. Dendritic cells, T-cell infiltration, and Grp94 expression in cholangiocellular carcinoma. Hum Pathol. 2004;35(7): 881-6.

57. Lim YJ, Koh J, Kim K, Chie EK, Kim B, Lee KB, Jang JY, Kim SW, Oh DY, Bang $Y J$, et al. High ratio of programmed cell death protein 1 (PD-1)(+)/CD8(+) tumor-infiltrating lymphocytes identifies a poor prognostic subset of extrahepatic bile duct cancer undergoing surgery plus adjuvant chemoradiotherapy. Radiother Oncol. 2015;117(1):165-70.

58. Kitano Y, Okabe H, Yamashita YI, Nakagawa S, Saito Y, Umezaki N, Tsukamoto M, Yamao T, Yamamura K, Arima K, et al. Tumour-infiltrating inflammatory and immune cells in patients with extrahepatic cholangiocarcinoma. Br J Cancer. 2018;118(2):171-80.

59. Morisaki T, Umebayashi M, Kiyota A, Koya N, Tanaka H, Onishi H, Katano M. Combining cetuximab with killer lymphocytes synergistically inhibits human cholangiocarcinoma cells in vitro. Anticancer Res. 2012;32(6):2249-56.

60. Jung $I H$, Kim DH, Yoo DK, Baek SY, Jeong SH, Jung DE, Park SW, Chung YY In Vivo Study of Natural Killer (NK) Cell Cytotoxicity Against Cholangiocarcinoma in a Nude Mouse Model. In Vivo. 2018;32(4):771-81.

\section{Publisher's Note}

Springer Nature remains neutral with regard to jurisdictional claims in published maps and institutional affiliations.

\section{Ready to submit your research? Choose BMC and benefit from:}

- fast, convenient online submission

- thorough peer review by experienced researchers in your field

- rapid publication on acceptance

- support for research data, including large and complex data types

- gold Open Access which fosters wider collaboration and increased citations

- maximum visibility for your research: over $100 \mathrm{M}$ website views per year

At BMC, research is always in progress.

Learn more biomedcentral.com/submissions 